\title{
DAMPAK COVID-19 TERHADAP PEMUTUSAN HUBUNGAN KERJA (PHK) DAN KETIDAKKOOPERATIFAN PERUSAHAAN DALAM MEMBERIKAN HAK KARYAWAN SETELAH DI PHK
}

\author{
Moh. Maruf, Riyan Sisiawan Putra \\ Fakultas Ekonomi Bisnis dan Teknologi Digital, Program Studi Manajemen Unusa \\ e-mail:drmakruf1971@gmail.com,riyan_sisiawan@unusa.ac.id
}

\begin{abstract}
The Covid-19 outbreak has had a very large impact, this study aims to provide an explanation of its impact on employees and what employees can do if they are laid off by the company, the rights that can be obtained and what paths can be taken if these rights are not fulfilled by the company. The research method in this study is a systematic literature review, which collects journals and then analyzes them. The result of this study is that the Covid -19 outbreak caused an economic downturn that had an impact on Termination of Employment (PHK). Where if the layoff is carried out and there is a dispute, then a mediation needs to be carried out to find a compromise until the last resort is in court.
\end{abstract}

Keywords: Covid-19, layoffs, employee rights

\section{PENDAHULUAN}

Sejak akhir tahun 2019, dunia dilanda sebuah wabah yang datangnya dari Cina yaitu virus Covid 19 dan sudah menyebar di 65 negara (data WHO, 1 Maret 2020). Hal ini mengakibatkan aktivitas di seluruh dunia menjadi berubah, yang dahulu mereka beraktivitas dengan bebas, sekarang banyak sekali pembatasan-pembatasan yang dilakukan sehingga hal tersebut membuat kebiasaan-kebiasaan baru, di antaranya adalah supaya masyarakat memakai masker dan menjaga jarak satu sama lain. Tentunya dampak dari wabah tersebut tidak hanya perubahan kebiasaan, namun juga ada perubahan dalam melakukan pekerjaan, di mana yang awalnya dilakukan secara offline sekarang banyak pekerjaan yang dilakukan secara online dikarenakan adanya wabah ini. Di dalam sisi perekonomian wabah ini menyebabkan perekonomian mengalami penurunan, hal ini disebabkan orang-orang lebih hati-hati dalam membelanjakan uangnya selain banyak juga tempat usaha yang di tutup di- karenakan di daerah-daerah dilakukan lockdown atau karantina. Karantina menurut UU Republik Indonesia Nomor 6 tahun 2018 tentang Kekarantinaan Kesehatan adalah pembatasan kegiatan dan/atau pemisahan seseorang yang terpapar penyakit menular sebagaimana ditetapkan dalam peraturan perundang-undangan meskipun belum menunjukkan gejala apa pun untuk mencegah kemungkinan penyebaran ke orang di sekitarnya (UU No. 6 tahun 2018). Hal tersebut memengaruhi pendapatan yang diterima oleh perusahaan. Perusahaan yang terdampak tentunya berusaha untuk bisa tetap bertahan dengan cara pengurangan tenaga kerja, atau mengurangi biayabiaya yang di anggap tidak terlalu penting. PHK itu sendiri tidak bisa dihindari dikarenakan supaya perusahaan bisa tetap bertahan, tetapi memang baiknya bila hal tersebut di ambil sebagai langkah akhir perusahaan mampu memberikan hak dari karyawan tersebut. Namun di dalam praktiknya masih banyak perusahaan yang tidak bisa memberikan hak karyawan ini. 


\section{Pemutusan Hubungan Kerja (PHK)}

Pemutusan Hubungan Kerja (PHK) berdasarkan Pasal 1 Ayat 25 Undang-Undang Nomor 13 Tahun 2003 tentang Ketenagakerjaan, didefinisikan bahwa PHK adalah pengakhiran hubungan kerja karena suatu hal tertentu yang mengakibatkan berakhirnya hak dan kewajiban antara buruh/pekerja dan pengusaha. Perselisihan pemutusan hubungan kerja (PHK) secara khusus diatur dalam Undang-Undang Nomor 2 Tahun 2004 tentang Penyelesaian Perselisihan Hubungan Industrial (PPHI). Dengan diberlakukan UndangUndang Nomor 2 Tahun 2004 tentang PPHI tersebut, Undang-Undang Nomor 12 Tahun 1964 tentang Pemutusan Hubungan Kerja di Perusahaan Swasta, dan Undang-Undang Nomor 22 Tahun 1957 tentang Penyelesaian Perselisihan Perburuhan (P3) dinyatakan tidak berlaku lagi.

Alasan-alasan yang dipandang sebagai alasan untuk menunjang pembenaran pemutusan hubungan kerja (PHK) yang dilakukan oleh pengusaha atas diri seorang atau beberapa pekerja menurut Sudibyo Aji Narendra Buwana dan Mario Septian Adi Putra adalah sebagai berikut.

1. Alasan ekonomis

a. Menurunnya hasil produksi yang dapat pula disebabkan oleh merosotnya kapasitas produksi perusahaan yang bersangkutan.

b. Merosotnya penghasilan perusahaan

c. Merosotnya kemampuan perusahaan tersebut untuk membayar upah dalam keadaan yang sama dengan sebelumnya.

d. Pelaksanaan rasionalisme atau penyederhanaan yang berarti pengurangan pekerja dalam jumlah besar dalam perusahaan yang bersangkutan.

2. Alasan tentang diri pribadi pekerja yang bersangkutan

a. Tidak memiliki kemampuan kerja dan prestasi yang memadai selaras dengan target yang telah ditentukan. b. Tidak memiliki tingkah laku yang baik: tidak jujur, kurang mempunyai rasa tanggung jawab, sering mangkir tanpa alasan dan lain-lain.

c. Tidak memiliki kekuatan jasmani yang sepadan dengan beratnya tugas yang diemban dan sebagainya.

d. Karena meninggalnya pengusaha dan tidak ada ahli waris yang mampu melanjutkan hubungan kerja dengan pekerja yang bersangkutan.

\section{Hak Karyawan atas PHK}

Hak-hak pekerja akibat PHK bisa dilihat di Pasal 1 Keputusan Menteri Tenaga Kerja Nomor Kep-150/Men/200 yaitu berupa hal-hal sebagai berikut.

1. Uang pesangon dapat diartikan sebagai uang yang harus dibayarkan oleh pengusaha kepada buruh/pekerja sebagai akibat dari adanya PHK.

2. Uang penghargaan masa kerja, dalam hal ini berupa uang yang wajib diberikan oleh pengusaha kepada para pekerja/buruh sebagai upah dalam hal lamanya masa bekerja peker$\mathrm{ja} /$ buruh yang bersangkutan.

3. Ganti kerugian uang, dalam hal ini merupakan upah yang diberikan oleh pengusaha kepada pekerja/buruh sebagai ganti terhadap kerugian yang dialami oleh pekerja/buruh tersebut karena akibat dari PHK, yaitu penggantian istirahat umum, istirahat panjang, biaya perjalanan ke tempat di mana pekerja diterima bekerja, fasilitas pengobatan, fasilitas perumahan, dan lain-lain.

Dari kepmen itu tentunya di harapkan para pengusaha mematuhi peraturan, bila terjadi PHK maka hal-hal tersebut harus dilaksanakan dan bila tidak dilaksanakan maka karyawan berhak untuk menuntut haknya tersebut. 


\section{METODOLOGI}

Di dalam penelitian ini menggunakan metode sistematik literatur review, di mana dilakukan pengkajian terhadap jurnal-jurnal yang ada dan disesuaikan dengan kenyataan. Sumber yang di ambil dalam penelitian ini adalah Google Scholar. Proses penyeleksian jurnal dengan cara mengelompokkan jurnal-jurnal tersebut berdasarkan kedekatannya dan dipilih yang paling sesuai dengan judul penelitian.

\section{HASIL DAN PEMBAHASAN}

\section{Covid-19 Menyebabkan PHK}

Dalam sebuah negara tentunya butuh penopang supaya perekonomian dan keberlanjutan negara tersebut bisa jalan. Tidak bisa hanya mengandalkan negara saja tetapi membutuhkan seluruh lapisan masyarakat untuk menjalankan perekonomian tersebut. Tentunya semua ini saling berkaitan satu sama lain di mana negara dan lembaga keuangan lain yang membuat kebijakan supaya perekonomian tetap berjalan sedangkan masyarakat yang menjalankan kegiatan perekonomian. Di masa wabah Covid-19 ini perekonomian di banyak negara mengalami banyak gangguan, penyebabnya banyak sekali di antaranya adalah pembatasan dalam berjualan dan banyak usaha yang mesti ditutup terlebih dahulu dikarenakan menimbulkan kerumunan dan takutnya warga terkena penyakit yang berdampak pada pengucilan warga yang kena dampak tersebut. Dari beberapa hal tersebut akhirnya menyebabkan perekonomian di sebuah negara itu turun. Salah satu contoh kecil bisa kita lihat di Banjarmasin di pasar apung dimana awalnya tempat tersebut adalah tempat pariwisata dan tempat berputarnya roda perekonomian daerah namun sekarang menjadi sepi karena wabah ini, hal ini seperti yang dikatakan oleh Abbas, E. W.,
Hidayat Putra, M. A., \& Noor Handry, M. R. (2019). 'Seperti ekowisata di bantaran Sungai Martapura tepatnya pada Kota Banjarmasin yang menjadi objek wisata terlebih khusus pada kota Banjarmasin, seperti halnya menjadikan sungai menjadi objek wisata, adanya pasar terapung, terletak pada Siring menara pandang, adanya wisata ini membuat atau mengedukasi masyarakat bahwasanya Sungai Martapura bisa digunakan menjadi objek wisata, adanya pasar terapung dapat juga meringankan beban ekonomi masyarakat sekitar, tetapi saat ini ketika munculnya Covid-19 pasar terapung tidak berjalan semestinya dan para pedagang lebih cenderung tidak berjualan, trauma psikologis menghindari psikomotis'.

Dari banyak sebab itu, bila diakumulasikan di seluruh Indonesia bisa jadi hal ini menjadi sangat besar sehingga memiliki dampak pada penurunan perekonomian negara. Hal ini sejalan dengan apa yang dikatakan oleh Lestari, J. A., Abbas, E. W., \& Mutiani, M. (2020). 'Pada dasarnya pemerintah sekarang mengambil kebijakan-kebijakan seperti penerapan PSBB bagi setiap kota yang terjangkit Covid-19 dan juga banyaknya penutupan dari segi tempat, dan tidak diperbolehkan membuat kerumunan keramaian, menerapkan social distancing yang membuat turunnya pendapatan tidak seperti hari biasanya sebelum adanya Covid-19 ini'. Sehingga perlu di ambil Langkah untuk menanggulangi hal ini supaya perekonomian negara bisa tetap jalan. Kenapa begitu, karena dampak bagi perusahaanperusahaan adalah pengurangan tenaga kerja dan bila banyak tenaga kerja yang dirumahkan maka daya beli dari masyarakat tersebut tentunya tidak ada. 'Dan juga semenjak adanya pandemi Covid-19 ini banyak orang yang kehilangan pekerjaannya banyak dari perusahaan yang melakukan PHK masal yang membuat karyawan tidak mempunyai pekerjaan yang semestinya demi 
mencegah dan mengurangi kerugian dikarenakan pandemi ini Syahruddin, S. (2020)'. Dan bila masyarakat tidak memiliki daya beli maka bisa jadi perekonomian di negara tersebut dalam keadaan mengkhawatirkan. Dari sana perlu hadirnya pemerintah supaya daya beli dari masyarakat ini masih ada.

\section{Apakah Covid-19 Termasuk Force Majeure}

Merujuk Pasal 164 Ayat (1) Undang-Undang Nomor 13 Tahun 2003 tentang ketenagakerjaan menyatakan, pengusaha dapat melakukan PHK pekerja/buruh karena perusahaan tutup yang disebabkan keadaan memaksa atau force majeure. Kemudian Pasal 164 Ayat (3) UU Nomor 13 Tahun 2003 menambahkan pengusaha juga dapat melakukan PHK pekerja/buruh karena perusahaan tutup bukan karena kerugian dua tahun berturut-turut atau bukan karena keadaan memaksa atau force majeure tetapi disebabkan efisiensi. Para pekerja/buruh ketika di PHK mendapatkan uang pesangon satu kali. Menteri Ketenagakerjaan, dalam pernyataannya terkait force majeure yang berkonsekuensi kepada para pekerja dengan memutus hubungan kerja tidak mendukung alasan-alasan perusahaan tersebut, Menteri Ketenagakerjaan mengimbau supaya perusahaan harusnya membuat langkah yang bisa ditempuh seperti; mengurangi upah dan fasilitas manajer juga direktur, mengurangi shift kerja, membatasi kerja lembur atau merumahkan buruh untuk sementara waktu. Namun beberapa perusahaan yang sudah mengeluarkan kebijakan untuk memutus hubungan kerja tetap beralasan mereka tidak memiliki dana yang cukup untuk membayar pesangon atau upah para pekerja. Hal tersebut menyalahi Peraturan ketenagakerjaan yang menyatakan bahwa perusahaan boleh tutup jika sudah mencapai kerugian selama dua tahun. Sedangkan Covid-19 ini belum men- capai atau memasuki satu tahun. Alasan force majeure yang dipakai oleh beberapa perusahaan tidak dapat diterima oleh beberapa kalangan.

Menurut Subekti, force majeure adalah suatu alasan untuk dibebaskan dari kewajiban membayar ganti rugi. Kemudian, dalam KUH Perdata tidak ditemukan istilah force majeure dengan tidak menjelaskan keadaan memaksa yang seperti apa yang dapat menjelaskan istilah force majeure. Namun memang ada beberapa istilahistilah yang dalam KUH Perdata yang mengatur tentang ganti rugi, risiko untuk kontrak sepihak kemudian diambil untuk istilah force majeure (Suadi). Dengan adanya force majeure tidak serta merta dapat di jadikan alasan perusahaan untuk berlindung dari alasan keadaan memaksa karena hanya ingin lari dari tanggung jawabnya, maka harus ada beberapa syarat supaya tidak terjadi hal demikian.

Berdasarkan yang dikatakan R. Subekti, suatu keadaan dikatakan force majeure ketika; keadaan itu sendiri di luar kekuasaan perusahaan dan memaksa, dan keadaan tersebut harus keadaan yang tidak dapat diketahui pada waktu perjanjian ini dibuat, setidaknya risikonya tidak dipikul oleh para pekerja yang di PHK. Dengan adanya beberapa syarat yang mesti dipenuhi, maka seseorang tidak dapat semaunya sendiri mengatakan dirinya mengalami force majeure. Dalam Pasal 47 ayat (1) huruf j UU 2/2017 tentang Jasa Konstruksi menjelaskan terkait force majeure. Menurut ketentuan pasal tersebut, maka force majeure dapat diartikan sebagai kejadian yang timbul di luar kemauan dan kemampuan para pihak yang menimbulkan kerugian bagi salah satu pihak. Keadaan memaksa tersebut meliputi beberapa hal sebagai berikut. 1. Keadaan memaksa yang bersifat mutlak (absolut) yakni bahwa para pihak tidak mungkin melaksanakan hak dan kewajibannya. 
2. Keadaan memaksa yang bersifat mutlak (relatif) yakni bahwa para pihak masih dimungkinkan melaksanakan hak dan kewajibannya.

Dalam hal ini covid-19, bisa disebut sebagai suatu peristiwa yang tidak terduga pada saat perjanjian atau kebijakan itu dibuat. Artinya jika ada perjanjian yang dibuat pada saat covid19 sedang menjalar dan menjangkit pemutusan hubungan kerja tidak dapat dijadikan alasan sebagai force majeure. Dengan demikian, maka perlu adanya perlindungan terhadap tenaga kerja untuk menjamin hak-hak dasar pekerja dan untuk mewujudkan kesejahteraan pekerja dengan tetap mementingkan perkembangan kepentingan perusahaan (Adisu \& Jehani, 2007).

\section{Bila Perusahaan Tidak Kooperatif}

Tentunya di dalam praktik tidak semua perusahaan mematuhi peraturan yang ada, sehingga perlu perhatian terhadap masing-masing perusahaan, supaya perusahaan tidak berperilaku sewenang-wenang terhadap karyawannya atau pekerjanya, di dalam Penjelasan umum UndangUndang Nomor 13 Tahun 2003 menyatakan bahwa pembangunan Ketenagakerjaan sebagai bagian integral dari pembangunan nasional berdasarkan Pancasila dan Undang-Undang Dasar Negara Republik Indonesia Tahun 1945, dilaksanakan dalam rangka pembangunan manusia Indonesia seutuhnya dan pembangunan masyarakat seluruhnya untuk meningkatkan harkat, martabat dan harga diri tenaga kerja serta mewujudkan masyarakat sejahtera adil, makmur, dan merata baik material maupun spiritual.

Dan bila ada ketidaksepahaman oleh dua kepentingan maka perlu adanya perjanjian kerja atau peraturan perusahaan dan perjanjian kerja bersama untuk menyatukan kepentingan kedua belah pihak tersebut agar dapat bersatu sehingga dapat dihindarkan terjadinya Pemutusan $\mathrm{Hu}-$ bungan Kerja (PHK). Menurut Pasal 171 Undang-Undang Nomor 13 Tahun 2003 dinyatakan bahwa karyawan yang mengalami pemutusan hubungan kerja tanpa penetapan lembaga penyelesaian perselisihan hubungan industrial yang berwenang dan karyawan yang bersangkutan tidak dapat menerima pemutusan hubungan kerja tersebut maka karyawan dapat mengajukan gugatan ke lembaga penyelesaian perselisihan hubungan industrial dalam waktu paling lama satu tahun sejak tanggal dilakukan pemutusan hubungan kerjanya.

Penyelesaian perselisihan dengan mediasi merupakan bentuk penyelesaian yang lebih kuat karena mediator diperbolehkan menawarkan usulan penyelesaian kepada pihak-pihak yang berselisih. Kelemahan masalah mediasi seringkali terjadi praktik penundaan karena sering terjadi ketidakhadiran para pihak yang berselisih baik pihak pengusaha maupun pihak karyawan atau pekerja, dan kesulitan dalam pelaksanaan hasil penyelesaian. Perselisihan hubungan industrial yang dapat diselesaikan melalui mediasi adalah sebagai berikut.

1. Perselisihan hak

2. Perselisihan kepentingan

3. Perselisihan pemutusan hubungan kerja (PHK)

4. Perselisihan antara serikat pekerja atau serikat buruh

Dari sana kita bisa memahami apabila terjadi perselisihan bisa dicari jalan keluarnya sehingga salah satu pihak tidak dirugikan. Tentunya melihat terlebih dahulu hak dari masing-masing yang beselisih sudah di penuhi apa belum. Apabila memang ada salah satu yang belum maka jalan yang bisa di tempuh adalah lewat mediasi. Namun bila lewat mediasi tidak bisa terselesaikan baru melalui pengadilan. 


\section{KESIMPULAN}

Dari penelitian ini yang bisa kita ketahui bahwa Covid-19 memang menyebabkan perekonomian menurun. Pengaruhnya kepada perusahaan-perusahaan yang ada adalah pendapatan yang berkurang, dan efek dari pendapatan yang kurang adalah pemutusan hubungan kerja. Langkah ini di ambil perusahaan dengan alasan menyelamatkan perusahaan tersebut supaya bisa tetap hidup. Tentunya bila dilakukan secara benar hal ini bakal tidak menjadi masalah, namun bila hal ini tidak benar maka menimbulkan masalah. Seperti tidak memenuhi hak karyawannya, sebagai contohnya tidak memberikan pesangon dengan alasan force majeure tentunya hal ini tidak dibenarkan. Bila hal ini terjadi karyawan berhak menuntut haknya lewat mediasi dan bila jalan ini tidak ketemu juga bisa langsung lewat jalan hukum.

\section{DAFTAR RUJUKAN}

Adisu, E. \& Jehani, L. (2007). Hak-Hak Pekerja Perempuan. Tangerang: Visi Media.

Abbas, E. W. \& W. Meilina, N. (2019). Religios Activities at Sultan Suriansyah Mosque Banjarmasin. The Innovation of Social Studies journal, 1(1), 55-64.

Buwana. S. A. N. \& Putra, M. S. A. (2015). Implementasi Pemutusan Hubungan Kerja (PHK) Terhadap Pekerja Status Perjanjian Kerja Waktu Tertentu (PKWT) pada PT $\mathrm{X}$ di Kota Malang. Jurnal Studi Manajemen, Vol. 9, No. 2, Oktober 2015.
Cristoforus Valentino Alexander Putra. (2017). Urgensi Klausula Definisi dalam Perjanjian Kerja. Kertha Patrika, Vol. 39, Hlm. 63. URL: https://ojs.unud.ac.id/index.php/ kerthapatrika/article/view/32709/19795.

R. Subekti. (1995). Aneka Perjanjian. Bandung: Intermasa.

Syahruddin, S. (2020). Menimbang Peran Teknologi dan Guru dalam Pembelajaran di Era Covid-19. ks-at-the-media-briefingon-2019-ncov-on-11-february- 2020. (Feb $\left.12^{\text {th }} 2020\right)$.

Suadi, H. A. (n.d.). Penyelesaian Sengketa Ekonomi Syariah.

UU No 6 Tahun 2018. Undang-Undang Republik Indonesia Nomor 6 Tahun 2018. Retrieved from https://sipuu.setkab.go.id/PUUdoc/ 175564UU\%20Nomor\%206\%20 Tahun\% 202018.pdf.

UU No. 13 Tahun 2003. (2003). Undang-Undang Republik Indonesia Nomor 13 Tahun 2003 tentang Ketenagakerjaan.

UU No. 2 Tahun 2004. (2004). Undang-Undang Republik Indonesia Nomor 2 Tabun 2004 tentang Penyelesaian Perselisihan Hubungan Industrial.

Warmansah Abbas, E. R. S. I. S. (2020). Menulis di Era Covid-19: Memanaje Trauma Psikologis Menghindari Psikomotoris Menulis di Era Covid-19: Memanaje Trauma Psikologis Menghindari Psikomotis.

WHO. (2020). WHO Director-General's Remarks at the Media Briefing on 2019-nCov on 11 February 2020. Cited Feb 13rd 2020. Available on:https://www.who.int/dg/speeches/detail/ who-director-generals-remar. 